\title{
NEOTECTONIC BASIN EVOLUTION IN CENTRAL-EASTERN MAINLAND GREECE: AN OVERVIEW
}

\author{
Kranis H. ${ }^{1}$ \\ ${ }^{1}$ National and Kapodistrian University of Athens, Faculty of Geology and Geoenvironment, \\ Department of Dynamic, Tectonic \& Applied Geology,hkranis@geol.uoa.gr
}

\begin{abstract}
The neotectonic evolution of central-eastern mainland Greece (Sterea Hellas) is documented in the result of local extensional tectonics within a regional transtensional field, which is related to the westward propagation of the North Anatolian Fault. The observed tectonic structures within the neotectonic basins and their margins (range-bounding faults and fault zones, rotation of tectonic blocks) suggest a close relation to the Parnassos Detachment Fault (PDF), which is a reused alpine thrust surface. Lokris basin (LB) occupied a central position in this neotectonic configuration, having received its first sediments in the Uppermost Miocene and subsequently been greatly affected by tectonic episodes, which continue until nowadays. $L B$ is considered to have been separated from the present-day North Gulf of Evia not earlier than the Lower Pleistocene. Voiotikos Kifissos Basin, on the other hand, is tightly related to the activation of $P D F$, occupying the position of a frontal basin and having developed along the main detachment front.
\end{abstract}

Key words: Lokris, detachment faulting, block rotation, North Anatolian Fault.

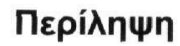

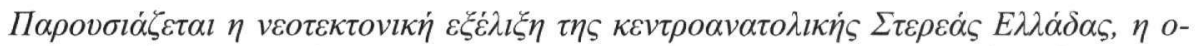

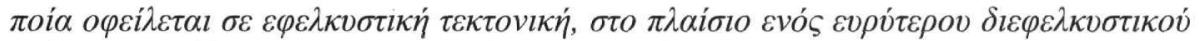

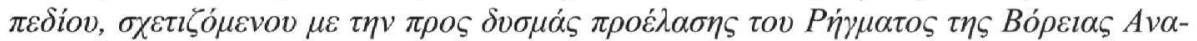

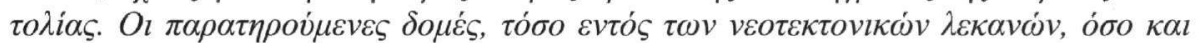

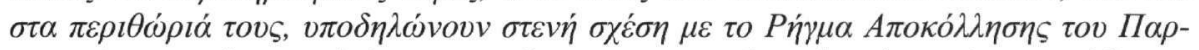

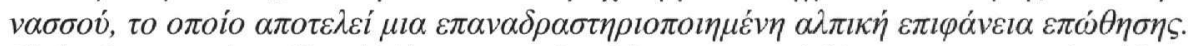

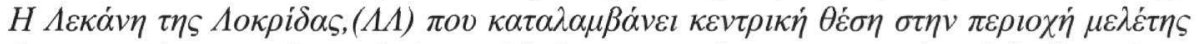

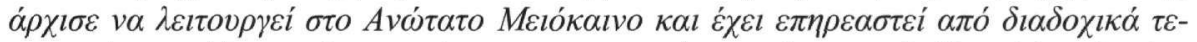

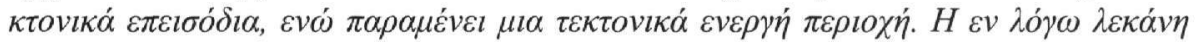

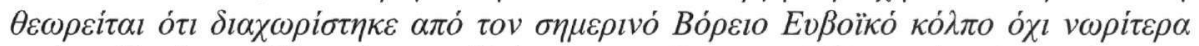

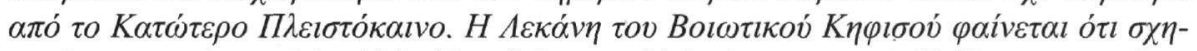

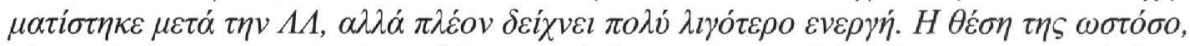

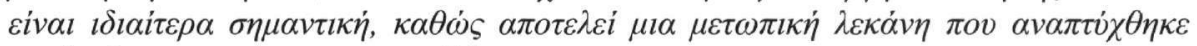

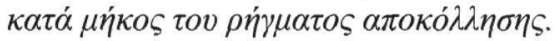

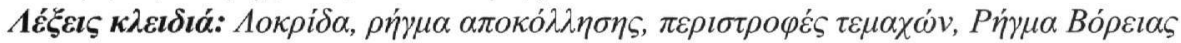
Avatoilis. 


\section{Introduction}

This paper will review stratigraphic and lithological data that constrain the ages of deformation and structural evolution of central-eastern mainland Greece ("Sterea Hellas"), which lies between two prominent, currently marine, basins in central Greece, namely the Gulfs of Corinth and Evia in the south and north, respectively (Fig.1). It is a tectonically active region, which has been affected by extensional-style tectonics, hosting well-known WNW-ESE tectonic structures, such as the Atalanti, Arkitsa- Agios Konstantinos - Kamena Vourla, and Kallidromon Fault Zones (Philip 1974, Roberts and Jackson 1991, Ganas and White 1996, and others) and others, oblique or transverse to these, as the Hyampolis fault (Palyvos et al. 2006) and the Bralos-Oiti Fault zone (Kranis and Lekkas 2000, Tzanis et al. 2004). In the last decade or so, it has been realized that central mainland Greece is undergoing mixed horizontal shear and extension (e.g. Taymaz et al. 1991, Armijo et al. 1996, Goldsworthy et al. 2001: Burchfiel 2004).

The core of this study was the Lokris Basin (LB), which is believed to host evidence of the tectonic activity for at least the last 6-8 My, since the Upper - Uppermost Miocene. The location, geomorphological, geological and tectonic characteristics of the LB are witnesses to successive tectonic episodes which are related not only to local but also to regional geodynamic processes. LB is an asymmetric graben, bounded on the south by the Kallidromon Fault Zone (KFZ). Between Mts Kallidromon and Parnassos - Giona lies the Voiotikos Kifissos Basin (VKB) (Fig.1), which owes its existence to tectonic activity on the NE margin of the Parnassos - Giona.

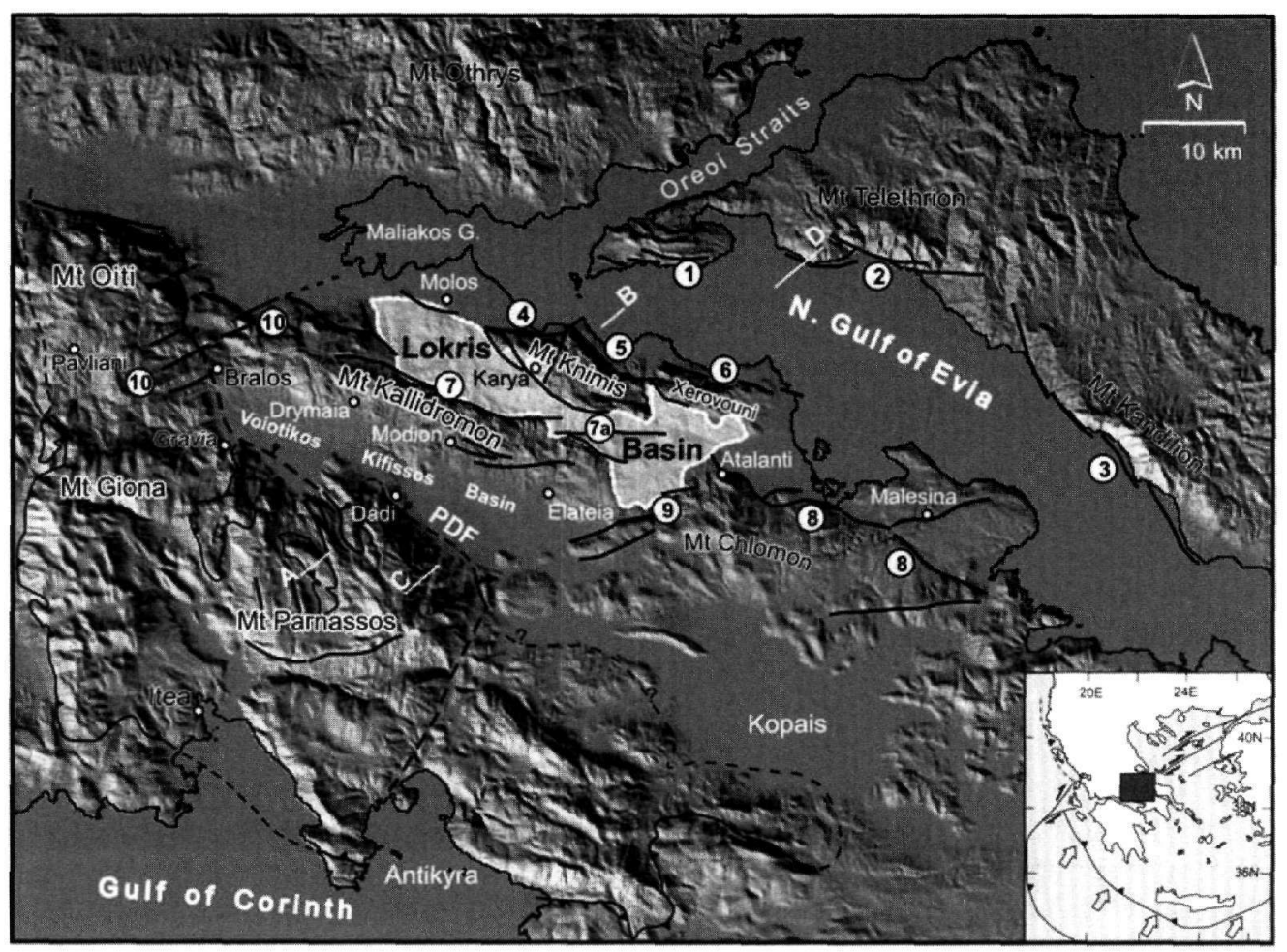

Figure 1 - Hillshaded relief of central-eastern mainland Greece. PDF: Parnassos Detachment

Fault; 1: Lichas Fault Zone; 2: Telethrion FZ; 3: Kandilion FZ; 4: Kamena Vourla FZ; 5: Agios Konstantinos FZ; 6: Arkitsa - Longos FZ; 7: Kallidromon GZ; 8: Atalanti FZ; 9: Hyampolis FZ; 10: Bralos-Oiti FZ. Lines AB and CD correspond to the sections of Fig. 6 


\section{Neotectonic Basins}

\subsection{Lokris Basin (LB)}

Lokris basin (the 'Renginio Basin' of Leeder and Jackson's, 1993) covers an area of $190 \mathrm{~km}^{2}$ and can be divided into two sub-basins, (Fig. 2), on geomorphological, tectonic and geologicstratigraphical criteria (see Kranis 1999 for discussion). It has an elongated, WNW-ESE form, with a length of $30 \mathrm{~km}$ and a maximum width of 8-9 km. Its southern-southwestern margin, formed by oblique-normal range-bounding fault zones (Kranis 1999), is the Kallidromon mountain complex, which includes Mts Elafovouni, Kallidromon and Sfingio. To the east-southeast it is partially bounded by Mt Chlomon and partially 'open' to the Atalanti plain. The northern boundary is mainly formed by the southern flanks of Mt Knimis and its eastward prolongation (Xerovouni); however, at the northwestern part, the basin is 'open', in the sense that it gives on directly to the alluvial plain of Molos. The basin is drained by a number of -mostly ephemeralstreams that discharge into the Northern Euboikos and Maliakos Gulfs. Many of these streams are deeply incised, cutting through the basin fill.

The sedimentary fill of the LB is or terrestrial (lacustrine and fluvial) origin, with the probable exception of a small outcrop close to the village of Renginion, where Dermitzakis and Papanikolaou (1981) and Dermitzakis (pers. comm.) suggested the occurrence of marine facies. Nonetheless, the basinal facies are not uniformly found throughout the basin and the absence of marker horizons makes the compilation of a single representative stratigraphic column quite difficult. However, the general stratigraphic configuration is as follows (Fig. 2b). (a) The oldest sediments are the Goulemi and the Karya formations, which crop out along the northern margin of the basin, now uplifted by neotectonic faults that mark the southern margin of Mt Knimis. The former is lignite-bearing and has an age of Uppermost Miocene - Early Pliocene, according on fossil mammal remains (Aceratherium), studied by Symeonidis (1974); Lemeille (1977) also reported fauna of the same age, but did not give further details. Palynological studies by Celet and Delcourt (1960) from the same area and examination of fossil flora from borehole samples (Ioakim, 1986) also indicated the same age. The Karya formation, composed mainly of multimictic and oligomictic conglomerates and breccias, has an estimated thickness of 150-200 m, presents irregular geometry and it is always found at altitudes higher than $400 \mathrm{~m}$ (Fig. 3). Actually, the peak of Mt Knimis, at $940 \mathrm{~m}$ a.s.1. is covered by this formation, the exact age of which remains uncertain. Nonetheless, it occupies a stratigraphic position analogous to that of the Goulemi one, that is to say, a basal formation overlain by the main sedimentation of the LB. (b) the area north of the basin axis and south of the aforementioned formations is covered by the Agnandi fm., a thick fluvio-lacustrine sequence of Pliocene to ?Early Pleistocene age. It consists of loose conglomerates alternating with sands, sandstones and silt (Fig. 3). Numerous exploratory boreholes sunk by Institute for Geology and Mineral Exploration (IGME) (Metaxas 1987; 1992; 1994) have given us a crude lithostratigraphic configuration of this formation. Specifically, it comprises (from bottom to top) fine, fossil bearing silt $(40-80 \mathrm{~m})$, followed by $20-90 \mathrm{~m}$ of clays and sands, $90-120 \mathrm{~m}$ of multimictic conglomerates (mainly ophiolitic clasts) and ends with several hundreds of $\mathrm{m}$ of oligimictic conglomerates (mainly carbonate pebbles) (c) The youngest one is the Renginion formation, which also contains lignite seams and outcrops south of the basin axis, with considerable surficial extent along the western margin and at the eastern portion of LB; it consists of fine sands, calcareous clays, sandstones and fine conglomerates, with a total thickness more than $300 \mathrm{~m}$ (Fig. 3). Philip (1974) mentioned the presence of proboscidean, Equus, Bos or Leptobos north of Rengini, Kranis (1999) reported the discovery of a Hippopotamus tusk north of Mendenitsa, and Athanassiou (2006) described remains of Eucladocerus sp and Mammuthus cf. meridionalis within these deposits. These findings as well as palynological analyses by Ioakim and Rondoyianni, (1988) from the lignites of Zeli, suggest that the age of this formation is (?)Latest Pliocene - Early Pleistocene. 
Flanking the basin, especially along its southern and western margins, are Quaternary scree and talus cones. A formation which belongs in the category of slope breccia is the Mendenitsa formation (Fig. 3), which occupies part of the SW margin of the basin. The topmost member of this formation was recognized by Philip (1974), as a very compact heterometric breccia (it is the main building material of the castle of Mendenitsa), similar to the breccias described by Sorel (2000) for the Kalavryta area, in N. Peloponnesus. The total thickness of the formation is approx $120 \mathrm{~m}$. It significance lies in the fact that it is faulted by the Kallidromon Fault Zone (Kranis 1999), thus providing satisfactory constraints on the activity of the KFZ.

The sediment geometry in the LB seems to follow a predictable pattern. The bedding dips are quite high, being usually around $30^{\circ}$. Very often, and especially in the middle part of the WLB and ELB, dip values are as high as $45^{\circ}$. The distribution of dip directions is in a quasi-amphitheatrical fashion, in the sense that, on average, dip directions in the western, central and eastern sections of the LB are southwesterly, southerly and southeasterly, respectively.

The relief of the basin is quite rough, especially in the WLB, where slope values can be as high as $40 \%$, while the mean altitude is $350 \mathrm{~m}$. The erosional planation surfaces are few, scattered and usually dipping. Most of them are related to the inclined bedding surfaces and usually coincide with erosion-resistant conglomerate or sandstone banks, forming a 'questa' landscape, particularly in the western portion of LB.

\subsection{The coastal landstrip}

The narrow landstrip between Mt Knimis and the N. Gulf of Evia can be distinguished in two sectors. The eastern one, around Arkitsa hosts outcrops of lacustrine and brackish facies (sands and fine sandstones (Arkitsa fm.), which Philip (1974) dated as Early- Middle Pleistocene. These sediments are overlain by characteristic argillaceous - silty banks bearing Viviparus (Paludina) which form a flat headland on the hanging-wall of the Arkitsa Fault; which Dewez (2003) interpreted it as consisting of two flights of terraces having been formed at 125 and $200 \mathrm{ka} \mathrm{BP}$, respectively. The Viviparus caprock is generally horizontal, while the underlying strata display gentle dips (most often less than $10^{\circ}$ ) without systematic orientation. The western sector includes sediments with lithostratigraphic and geometrical characteristics analogous to the Upper Formation of the LB. These are fluviolacustrine conglomerates, silts and sands, with steady S-SW dips in the range of $10-20^{\circ}$. South of Agios Konstantinos, these deposits are overlain by horizontal banks of compact breccia, while towards the west they are covered by recent scree. The limited extent of these outcrops and the scarcity of natural or artificial sections did not allow for more detailed investigation. Nevertheless, their facies and geometry suggest their affinity with the upper members (Pliopleistocene - Early Pleistocene) of the deposits in the LB.

\subsection{Voiotikos Kifissos Basin (VKB)}

It is a part of the catchment of the Voiotikos Kifissos River and can be divided into two sub-basins, which correspond to the upper and median flow sections of the river. The size of the basin is in the order of $400 \mathrm{~km}^{2}$, with the two sub-basins covering approximately equal areas. The two sub-basins are divided by a narrow passage close to Amfikleia (Fig. 5), where the alpine basement is exposed and Voiotikos Kifissos River flows through the limestones and dolomites of the Sub-Pelagonian Unit and erodes its Late Quaternary deposits (fluvial terraces).

The relief in both sub-basins is smooth, with a mean altitude of $250 \mathrm{~m}$. and the maximum slope value not exceeding $10 \%$. A large part of the VKB is an extended alluvial plain, with the Late Pleistocene - Holocene deposits of the river having covered the underlying sediment fill.

The sedimentary fill of the basin has limited thickness, and it mostly consists of Late Quaternary alluvial plain deposits. Especially for the western (upper) sub-basin, the alluvial cover is quite thick, reaching even $100 \mathrm{~m}$. or more, as confirmed by geophysical soundings carried by IGME (Tsioumas 1998, pers. comm.). 


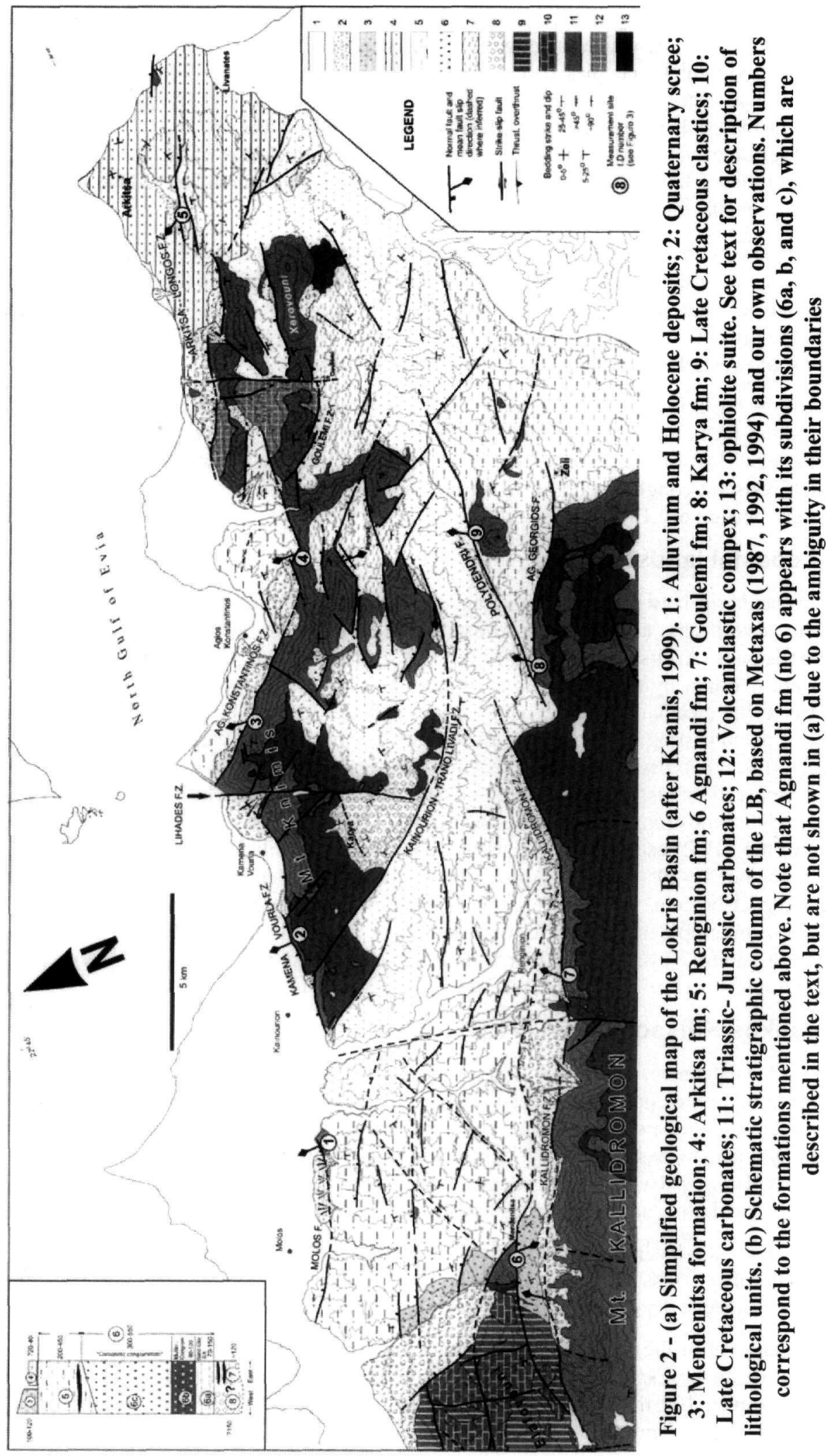



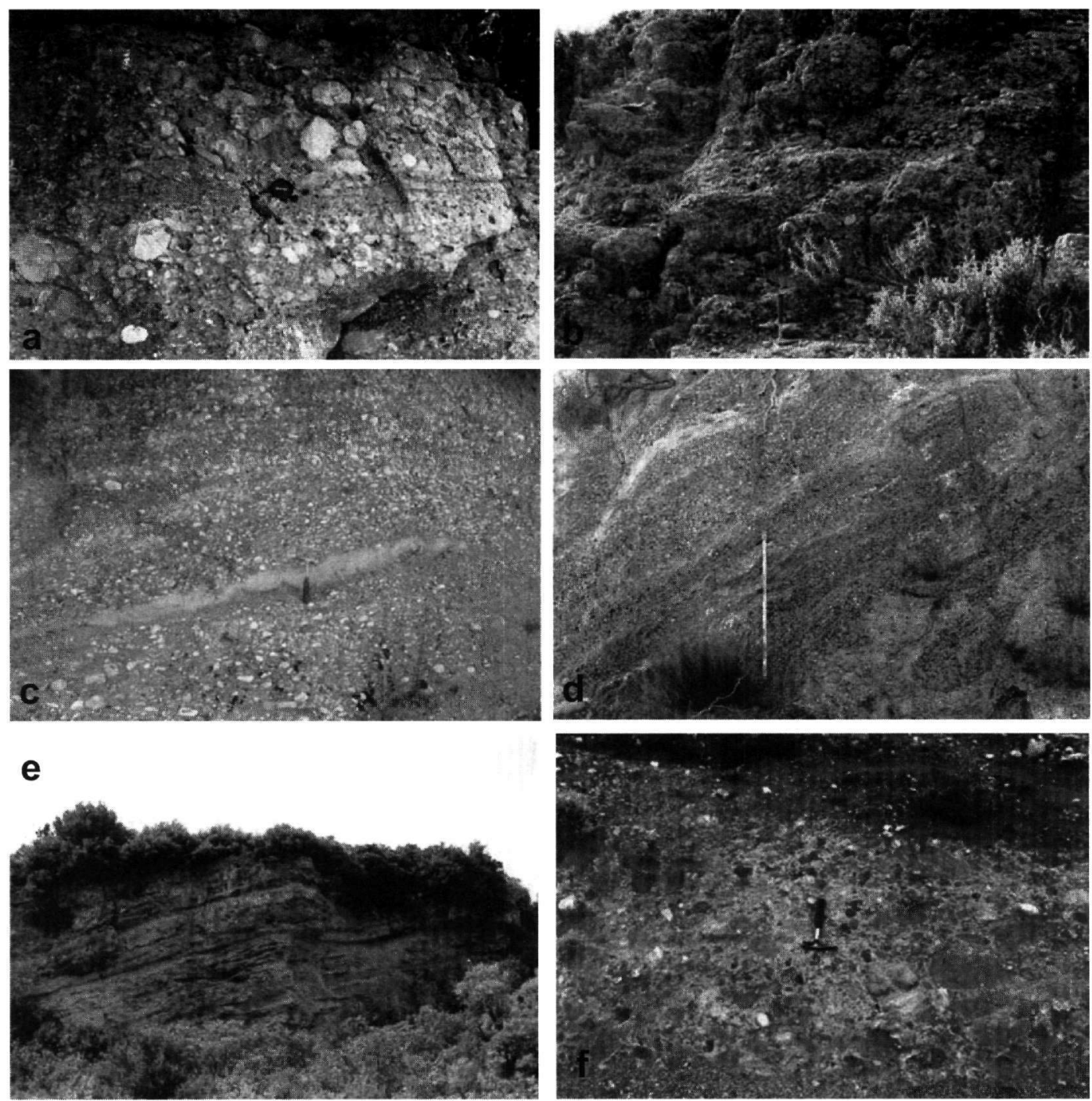

Figure 3 - Field photos from outcrops in Lokris. (a) the basal members and (b) the ologimictic conlomerates of the Karya fm. Lens cap and hammer for scale; (c) typical exposure of the Agnandi fm; (d) The steeply dipping fine conglomerates of the Renginion $\mathrm{fm}$. Dip direction is SSW; (e) the compact carbonate breccias that form the upper member of the Mendenitsa formation; (f) typical exposure of the reddish conglomerates in Drymaia

The age of the oldest sediments, which outcrop at the northern flank of the western sub-basin, close to Drymaia, and the northwestern edge of the eastern sub-basin, close to Modion, remains questionable. These are multimictic conglomerates in reddish clayey matrix, with clasts of various lithological types (sandstones, pelites, calcareous and igneous), with a thickness of approximately 100-150 m at Drymaia and less at Modion (Fig. 3). Based on lithological criteria, Celet (1962) regarded them as molassic remnants, presumably of Oligocene - Miocene age; however, this dating cannot be ascertained. Upon them is deposited a series of fluviolacustrine origin (150 maximum thickness), almost identical in character to the younger (Pliopleistocene- Early Pleistocene) deposits of the LB. However, the surficial outcrops of these deposits are limited a portion of the southern flanks of Mt Kallidromon, close to the village of Modion. The contact between these deposits and the underlying conglomerates can only be seen in a hill NE of Modion, as at other locations it is either covered by recent deposits (i.e. south of Drymaia) or it is faulted. 
The outcrops of all these deposits are located north of the basin axis, along the southern flanks of Mt. Kallidromo; the general dip direction is southerly. Towards the south there is no indication for their underlying the alluvial fill and their thickness seems to taper out towards the south. Their dips are generally gentle, not exceeding $10-15^{\circ} \mathrm{S}$.

The southern margin of VKB, especially along the foot of Mt Parnassos is covered by extensive scree and talus cones. According to Pope (2000) the most dominant of these alluvial fans, (the Tithorea fan) was initiated in the Upper Pleistocene and developed through the Holocene, in successive episodic stages. The basement of the basin is found at an altitude about at sea level and for the eastern sub-basin is the carbonates of the Sub-Pelagonian Unit, while for the western it is partially a clastic formation, probably corresponding to the flysch of the Parnassos Unit.

\subsection{Observations on marginal and interbasinal tectonic structures}

Kranis and Papanikolaou (2001) showed that the NE margin of Mt Parnassos corresponds to a large detachment fault (PDF), with the hanging-wall Triassic dolomites of the Subpelagonian Unit overlying a thin slice of the flysch pelites of the Parnassos Unit. PDF is a reused (alpine thrust) surface, with extensional tectonic features overprinting the older (alpine) ones. The mean slip vector, calculated from data from a quarry exposure at Dadi hill and at Toufa, SW of Amfikleia, is oriented NE (Figs 4, 5). Within the VKB tectonism has left few marks, with the exception of the antithetic fault set of Elateia (Fig 1). Along its western margin several NE-SW transverse faults have been located, belonging to the Pavliani (or Bralos-Oiti) Fault Zone (Lekkas and Kranis 2000, Tzanis et al. 2004).

LB shows signs of intense tectonic activity, both within the basin itself and along its margins. The sedimentary fill is densely faulted and tilted, usually towards the S, SSE or SSW and small-order horsts have formed within the basin (Mariolakos et al. 2001). The Kallidromon Fault Zone (KFZ) displays characteristics of oblique-normal (dextral) displacement, contrary to the coastal fault system (Arkitsa-Longos, Agios Konstantinos and Kamena Vourla Fault Zones) which displays constant sinistral oblique-normal movement (Figs 4, 5). Except for its eastern segment (which will be described later) the KFZ shows no signs of Late Quaternary activity. Cemented scree cover the entire mountain foot, from Renginion to Mendenitsa, with the exception of a well-developed alluvial fan at the village of Kallidromos. Fault surfaces are poorly preserved especially close to Mendenitsa, where the tectonized footwall dolomites have been eroded (Fig. 5). Few, but eroded slickensides are found south of Renginion, at the exit of the new railway tunnel and a fractured zone (but not the main fault surface itself) is exposed SW of the village of Kallidromos. West of Renginio, where the KFZ takes an E-W strike, it juxtaposes the erodible ophiolite suite against loose scree, but no fault surfaces have been found. On the other hand, the eastern part of the KFZ, which is represented by two overlapping segments, the E-W Polydendri f. and the WNW-ESE Agios Georgios f., displays rather "fresh" and well-preserved fault surfaces. Especially Polydendri f., which dips around $40-45^{\circ} \mathrm{N}$ has a well exposed, striated fault surface and is associated with an impressive, $\sim 250 \mathrm{~m}$ high escarpment (Fig. 5); the Agios Georgios f. has gentler dips and its surface is more eroded. One could assume that the Polydendri f. has rotated and replaced the Ag. Georgios f.: both of them however, have almost identical mean slip vectors (Fig. 4), so the possibility that the Ag. Georgios fault is still active cannot be ruled out.

The southern margin of Mt Knimis is partially formed by the Kainourio - Trano Livadi Fault Zone (KTLFZ), which displays 'peculiar' characteristics, the most important of which is that it is found with steep northerly dips northerly dips (instead of southerly, as one should expect), albeit being apparently an antithetic structure to the KFZ. Moreover, its striated fault surface gave a mean displacement vector oriented WNW.

Mt Knimis itself is a highly faulted, elongate 'horst' block, hosting several smaller-order faults (Fig. 2). On the coastal fault system equally important is the NW-SE main segment of the Agios Konstantinos f., which displays dip not higher that $35^{\circ}$ and slip vectors invariably oriented towards 
the North (Fig. 5). The faults east of west of the AKFZ are the Kamena Vourla F.Z. and the Arkitsa F.Z., respectively and their mean strike is WNW-ESE and dips are considerably higher, around $60^{\circ}$, on average. In other words, the AKf is oblique to the other two coastal fault systems. The same goes for a number of NW-SE, NE- or SW-dipping normal faults, located between the villages of Agnandi and Goulemi. The northernmost of them is the Paliompoukriza $\mathrm{f}$. (location 4 in Fig. 2), which is now linked with the AKf. This NW-SE fault presents two sets of slip vectors. The younger one, oriented $\mathrm{N}$ and consistent with the kinematics of the AKf and an older one, which is dip-slip (Fig. 5). Our investigations so far have not brought to light any piece of evidence for an older, dip-slip movement for the AKf itself, despite its proximity and identical orientation with the aforementioned NW-SE fault set.
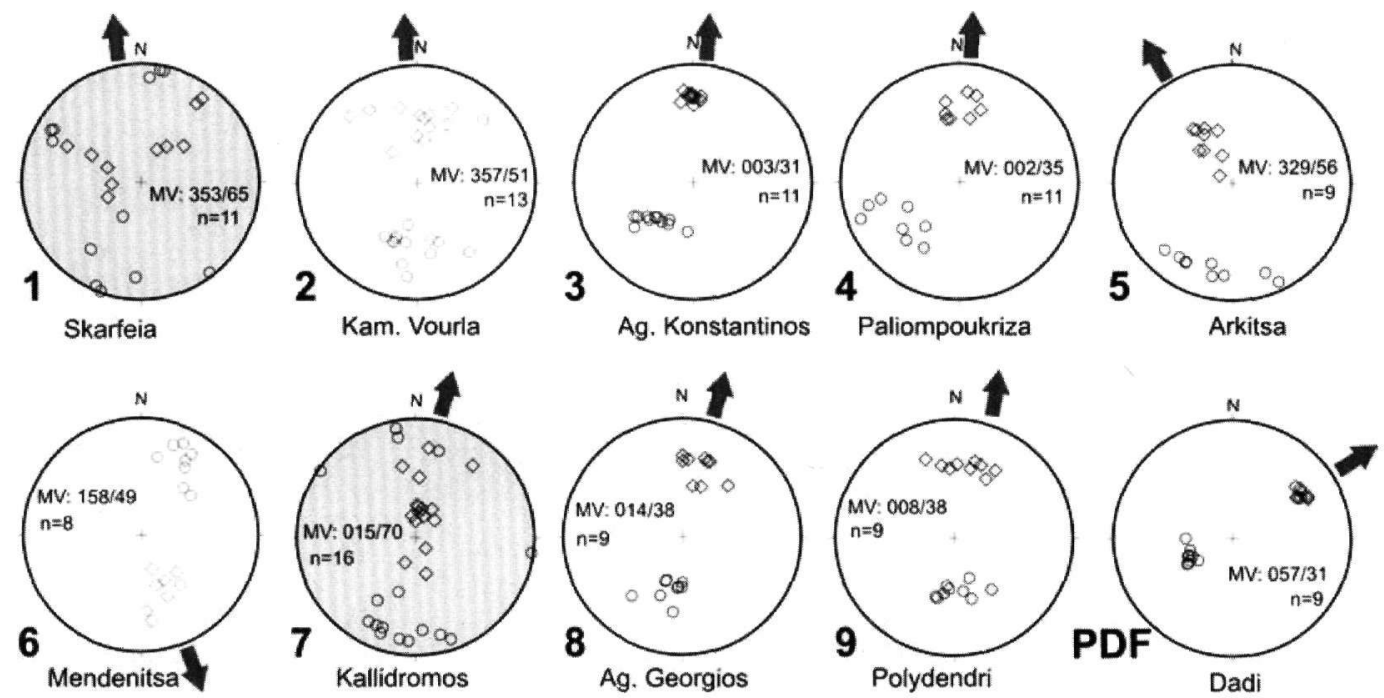

Figure 4 - Lower hemisphere stereographic projections of fault-slip data. Diamonds are lineations on fault planes, circles are poles to planes. MV: mean lineation orientation from Fischer statistics. White stereonets are for data from the main fault planes; gray ones for data from footwall fault arrays within $\sim 10 \mathrm{~m}$ from the main fault plane. For location of measurement stations see Figures 1 and 2

The eastern and western boundaries of LB and VKB, seem to be (at least partially) controlled by oblique or transverse fault zones, the kinematics of which are oblique-normal to strike-slip, such as the Hyampolis Fault Zone (Kranis et al. 2001, Palyvos et al. 2006) and the aforementioned BralosOiti FZ.

\section{Discussion and Conclusions}

The understanding of neotectonic evolution of the studied area calls for good age constraints; unfortunately, these are, to some degree, lacking, so what follows in this section is a working hypothesis on deformation rates, based the few available biostratigraphical data and lithostratigraphical correlations; further work involving dating can greatly improve this story.

The onset of lacustrine sedimentation is placed at Uppermost Miocene, with typical basal facies in Goulemi - Agnandi. During the same period, lacustrine sediments also started to be deposited in the area of Malesina; however, there is no proof that these two locations formed part of a greater lacustrine system. Deposition was also taking place in Karya, albeit with different litholological characteristics, owing to the difference in bedrock material (ophiolites instead of carbonates). 

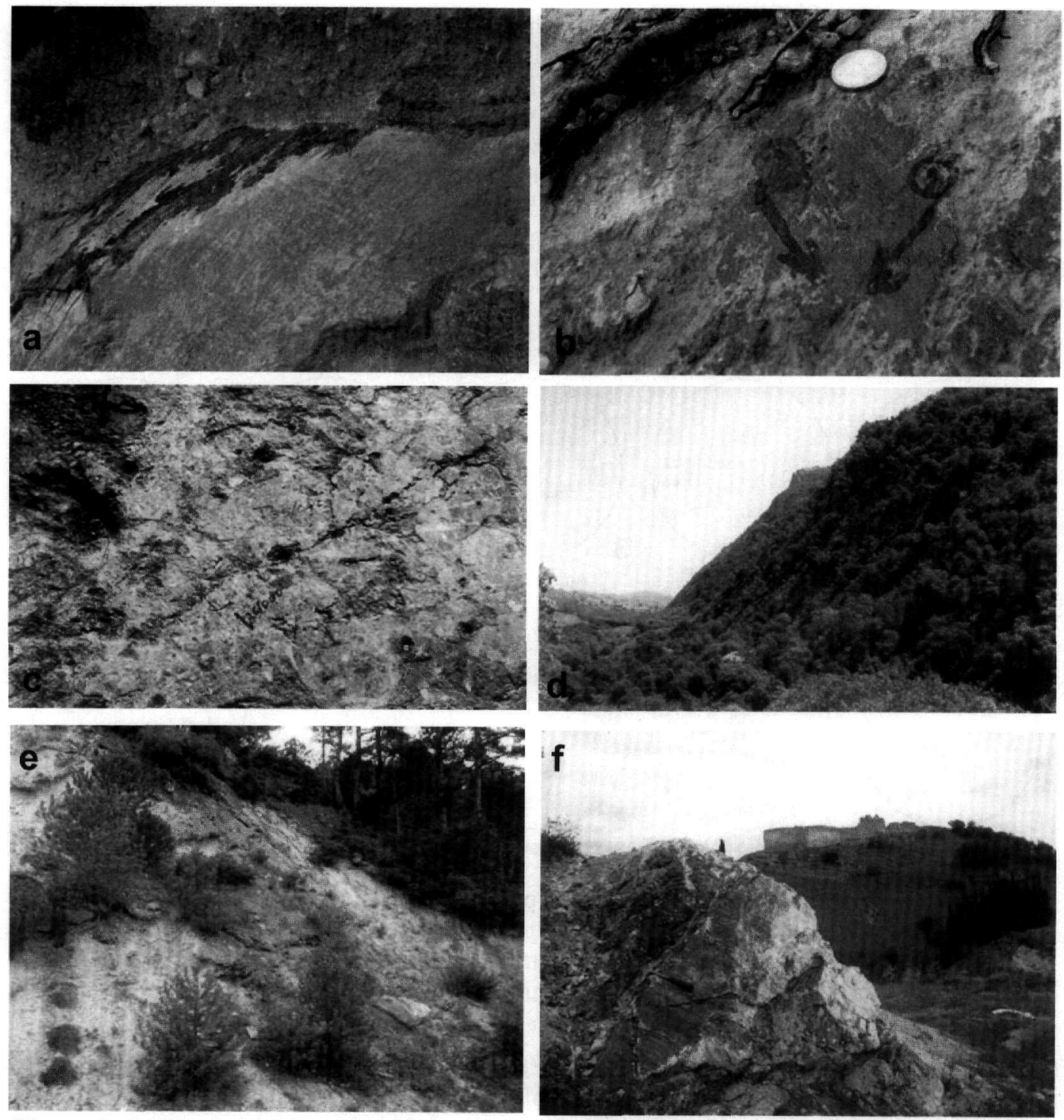

Figure 5 - (a) Fault surface of the Paliompoukriza $f$. and (b) close-up at the same location, to show the two sets of striations: oblique-slip postdates dip-slip; (c) striated slickenside of the AKf; (d) the Polydendri f. fault scarp here is $\sim 200 \mathrm{~m}$ high; (e) eroded fault surface of the KFZ, west of Mendenitsa; (f) the striated surface of the antithetic fault of KFZ at Mendenitsa. View to NE

Tectonic activity resulted in the uplift of the Uppermost Miocene - Early Pliocene sediments, which are now found at high altitudes, in Karya, Agnandi and Goulemi. The NW-SE set of faults between Agnandi and Goulemi may have also been formed during these early stages. This period also marked the start of the uplift of the coastal mountain range; however this uplift has not been uniform throughout the extent of Mt Knimis and its eastern prolongation, Xerovouni, as will be discussed later.

Whether the Voiotikos Kifissos basin had opened during that period or not cannot be established easily, considering the lack of biostratigraphical information. The age of reddish conglomerates of Drymaia and Modion remains uncertain: this could provide a good lower age limit. What we do know is that there are no lignite-bearing sequences, which could be analogous to the Goulemi fm., 
while the thick conglomerate series of the LB (Agnandi fm.) are also absent. The formations that overlie the reddish conglomerates are lithostratigraphically similar to the Renginion $\mathrm{fm}$. Should this be the case, then the VKB must have been s a small, narrow and elevated (intermontane) basin, above the level of fluvio-lacustrine sedimentation, within an extended mountain mass that corresponded to the current Mts Parnassos and Giona in the south and Kallidromon in the north.

The end of Pliocene - and probably until the Lower-Middle Pleistocene- is characterized be widespread fluviolavustrine sedimentation, albeit of varying depositional environments. These sediments are also found outside the present geomorphological borders of LB, such as (i) in Modion - Elateia, at the southern slopes of Mt Kallidromon, (ii) in Arkitsa (with significantly different lithostratigraphical characteristics); (iii) north of Gravia and covering the Bralos pass, between Mts Kallidromon and Oiti. In other words, the continental sedimentation during this period was extensive, covering the greatest part of the broader Lokris region. The present-day mountain masses were not yet uplifted in their current position, appearing as isolated bedrock salients, half-buried under the thick Early Pleistocene deposits. Jackson (1999) reported the occurrence of granite pebbles at the base of the Renginion formation: the source of these clasts must have been either to the north of the LB, which means, according to the same researcher, that they could not have been transported there if the coastal faults were active then.

Between Middle and Upper Pleistocene, tectonic activity increased significantly to the degree that it resulted in dramatic changes in the Lokridian landscape. Mt Kallidromon almost reached its present form, being a distinct, elongated fault block which underwent rapid uplift, the amount of which may have been smaller in the east than in the west. This suggestion is based both on geomorphological observations (the altitude of the erosional planation surfaces along its ridgeline lowers gradually towards the east (Kranis 1999) and on the basis of the altitude of the ophiolitic nappe, which also diminishes in the same direction. The formation and uplift of the elongated Kallidromon block separated the main bulk of the LB sedimentary fill from the isolated outcrop between Modion and Elateia, at the southern flanks of the mountain.

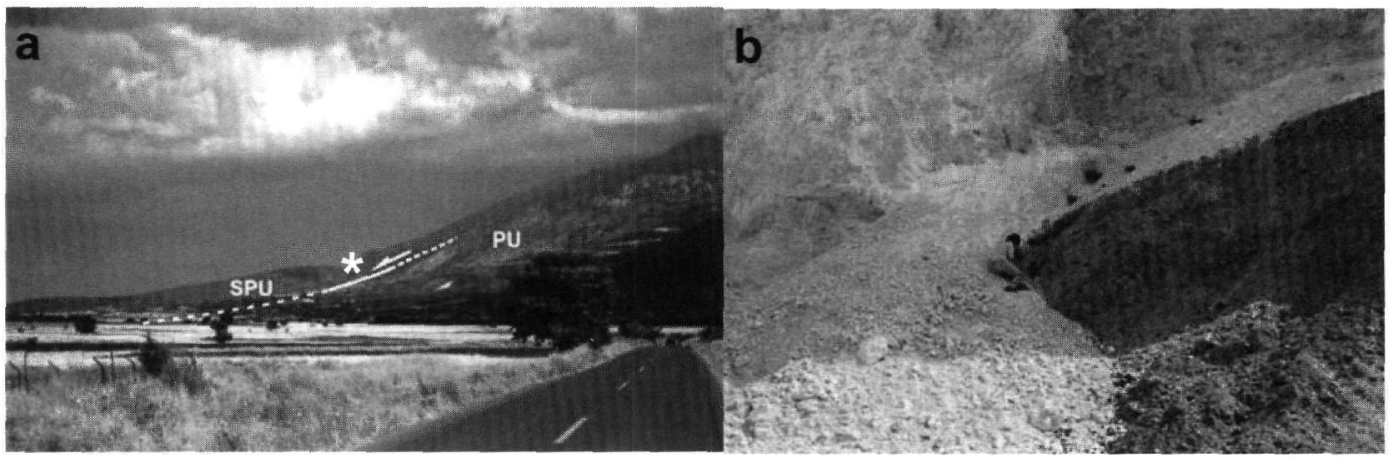

Figure 6 - (a) The Parnassos Detachment Fault (PDF) at Dadi Hill, Amfikleia, on the northern slopes of Mt Parnassos. View to ESE. PU: Parnassos Unit; SPU: Sub-Pelagonian Unit. Dadi hill is a characteristic turtle-back form, located just on the detachment front. Asterisk marks the location of (f): The PDF exposed in an abandoned quarry. The surface dips to the left $(\mathrm{N})$ and away (NE) from the viewer

The LB itself acquired much of its present form, too. The coastal mountain range (Knimis Xerovouni) was also uplifted as a minor but complex fault block, blocking partially the communication with the basin and the Northern Gulf of Evia. The coastal strip of Pleistocene sediments NW of Agios Konstantinos is a case similar to those in Modion, being cut off from the main body of the fluviolacustrine sequence, as a result of tectonism.

As was also the case of Mt Kallidromon, the uplift of Mt Knimis was not uniform, either, being much higher at the eastern end (Goulemi - Melidoni), where the volcaniclastic base of the 
sedimentary platform is exposed, than in the western end (Thronion), where the ophiolite tectonic cover is found at very low altitudes (Kranis 2002). However, the uplift of Knimis may have also been influenced by the set of NW-SE faults mentioned above, which might have caused an initial amount of uplift in the Pliocene, before the formation and the activation of the coastal fault system which gave Knimis its present form. Another observation has to do with the relationship of the NW-SE fault system to the coastal faults and especially the Agios Konstantinos $\mathrm{f}$. The two sets of striations on the Paliompoykriza $\mathrm{f}$, which is now linked with the AKf, may reflect the evolution of this particular structure, in the sense that in its first period of activity moved as a dip-slip normal fault, but its kinematics changed when it became linked with the coastal fault zone.

Tectonically-induced block rotation was has been a striking result of this tectonic phase. This has been confirmed both by observations in the horst-blocks (Mts Kallidromon and Knimis) and within the LB. where all fault blocks have been rotated towards the S-SSW. This block rotation is corroborated by the following observations: (i) in Mt Knimis, uplift has been significantly greated in its eastern part. On top of that, rotation has also taken place around a horizontal WNW-ESE axis, towards the south. This is shown in the very low dip values of the NE-dipping Agios Konstantinos Fault (not exceeding $35^{\circ}$ ), together with the rotation observed along the southern margin of the mountain, marked by the Kainourio - Trano Livadi Fault Zone (KTLFZ), which Kranis (1999) wrongly interpreted as a reverse fault, as it is a formerly S-dipping fault, now rotated by $25-35^{\circ}$ to steep northerly dips. (ii) within the LB, the Agnandi and Renginion formations are found dipping towards the $\mathrm{S}, \mathrm{SSW}$ and SSE with dip values around $30-35^{\circ}$, reaching even $45^{\circ}$ at places. This type of sediments is not expected to be deposited always horizontally, as the fluvial deposits tend to dip away from their source region, which was, in all probability, the elevated mountain ranges in the south. In other words, the sedimentary basin fill may have been rotated more than $35^{\circ}$ towards the south. Rotation has also affected the Mendenitsa formation, which is found tilted up to $40-45^{\circ} \mathrm{S}$.

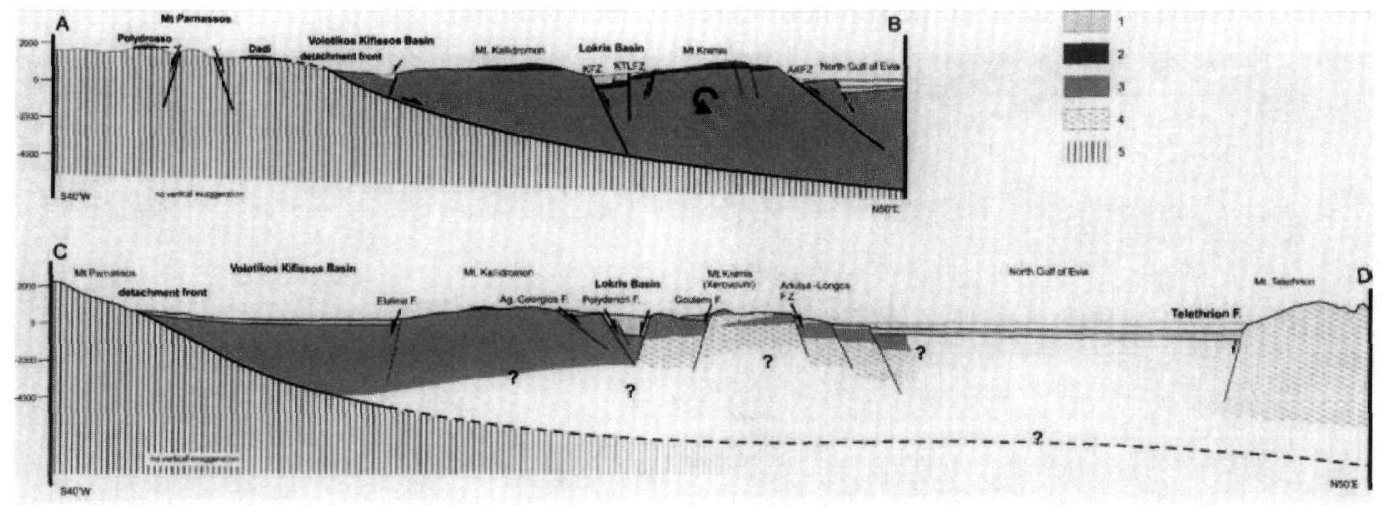

Figure 7 - Interpretative cross-sections through the Lokris and Voiotikos Kifissos Basins (see Fig. 1 for location). 1: Synrift deposits (Pliocene- Quaternary); 2: Ophiolite suite; 3: SubPelagonian Unit; 4: volcaniclastic complex and basement of the SPU; 5: "Lower Plate" formations, which correspond (at least in the western parts) the Parnassos Unit. The formation of both VKB and LB is attributed to the NE-ward sliding on the PDF. Section AB demonstrates the block rotation of Mt Knimis, resulting in the low dips of the AKFZ and the northerly dips of the originally S-dipping KTLFZ. This pattern is confirmed by the systematic southward lowering of the base of the ophiolite nappe. Section CD shows the uplifted volcaniclastic basal complex of the SPU, at the area of Melidoni, which may be linked to the SPU basement, outcropping just across the N. Gulf of Evia, on Mt Telethrion. The suggested shallowing of the detachment surface beneath the Gulf is believed to reflect the crustal thinning observed at this area (Makris et al. 2001) 
The aforementioned observations and suggestions are in agreement with the general concept of a northward fault migration (Goldsworthy and Jackson 2001) and fault-block rotation. Trying to understand the driving mechanism behind this, we investigated the southernmost extensional structure in the area, which marks the NE NE margin of Mts Parnassos, Giona and Oiti. Kranis and Papanikolaou (2001) called it the Parnassos Detachment Fault (PDF) (Figs 1, 3, 6, 7) and demonstrated that this is a reused (originally a thrust) surface. The timing of activity on this structure cannot be easily established, due to the absence of appropriate stratigraphical markers. It may have been a mobile zone that responded to the propagation of the North Anatolian Fault, on its reaching the Hellenic (present-day) mainland and giving rise to what Sengör (1979) called "Grecian Shear Zone". The fact that the central mainland Greece is undergoing mixed horizontal shear and extension has been shown by GPS surveys (e.g. McClusky et al. 2000) and has been reviewed by Burchfiel (2004). In this sense, the PDF is thought to be the northernmost of a series of WNW-ESE to NW-SE transtensional structures that have responded to the NAF propagation, which in combination with the ongoing back-arc dynamics have given rise to extensional structures, including the Gulf of Corinth (Dewey and Sengör 1979, Armijo et al. 1996, Burchfiel 2004). However, there are several questions to be answered yet. One is whether the observed neotectonic deformation is indeed confined within this approximately $35-40 \mathrm{~km}$ wide NE-SW zone, which includes LB, VKB, and the NW parts of the N. Gulf of Evia and the island itself, or it extends further to the SE (and less possibly to the NW). If the former suggestion is valid, then the observed transverse, NE-SW tectonic structures may exert significant tectonic control in the active tectonics of the region. However, for this to be verified, further research is needed, especially along the SPU alpine thrust front and the related basins (such as the Kopais Basin), for extensional neotectonic overprints.

\section{Acknowledgments}

Prof. J. Jackson and Dr G. Roberts and are thanked for their highly useful reviews of the manuscript. Professor D. Papanikolaou and colleagues Dr E. Skourtsos and L. Gouliotis are thanked for constructive discussions.

\section{References}

Armijo, R., Meyer, B., King, G.C. P., Rigo, A., and Papanastassiou, D., 1996.Quaternary evolution of the Corinth Rift and its implication for the late Cenozoic evolution of the Aegean, Geophysical Journal International, 126, 11-53.

Athanassiou, A., 2006. Reghinio, a new mammal locality from the Plio-Pleistocene of Central Greece, N. Jb. Geol. Paläont. Mh., 2, 116-128.

Burchfiel, B.C., 2004. New Technology: new geological challenges, GSA Today, 14, 4-9.

Celet, P., 1962. Contribution a l'étude géologique du Parnasse-Kiona et d'une partie des régions méridionales de la Grèce continentale, Ann. Geol. de Pays Hellen., XIII, 1-446.

Celet, P., and Delcourt, A., 1960. Les terrains néogènes de Locrides (Grèce orientale moyenne): leur situation géologique et leur age, Ann. Soc. Geol Nord, LXXX, 1125-132.

Dermitzakis, M.D., and Papanikolaou, D.J., 1981. Paleogeography and Geodynamics of the Aegean region during the Neogene, Proc. VIIth Intern. Congress on Mediterranean Neogene, Athens, 27September- 2 October 1979, 245-289.

Dewey, J.F., and Sengör, A.M., 1979. Aegean and surrounding regions:complec multiplate and co ntinuum tectonics in a convergent zone, Geol. Soc. Amer. Bull., 90, 84-92.

Dewez, T., 2003. Geomorphic markers and digital elevation models as tools for tectonic geomorphology in Central Greece, Unpubl. PhD Thesis, Brunel University, 173pp. 
Ganas, A., and White, K., 1996. Neotectonic fault segments and footwall geomorphology in Eastern Central Greece from Landsat TM data, Geol. Soc. Greece Sp. Publ., 6, 169-175.

Goldsworthy, M., and Jackson, J., 2001. Migration of activity within normal fault systems: examples from the Quaternary of mainland Greece, J. Struct. Geol., 23, 489-506.

Goldsworthy, M., Jackson, J., and Haines, J., 2001. The continuity of active fault systems in Greece, Geoph.J. Int., 148, 596-618.

Ioakim, C., and Rondoyanni, T., 1988. Contribution à l'étude géologique de la région de Zeli, Locride (Grèce centrale), Rev. de Micropal., 31, 2, 129-136.

Ioakim, Ch., 1986. Palynological - Stratigraphical study of the L3 borehole in Agnandi, Lokris, IGME Unpubl Report, Athens, 4p. (in Greek)

Jackson, J., 1999. Fault death: a perspective from actively deforming regions, J. Struct. Geol., 21, $1003-1010$.

Kranis, H.D., and Papanikolaou, D.I., 2001. Evidence for detachment faulting on the NE Parnassos mountain front (Central Greece), Bull. Geol. Soc. Greece, XXXIV/1, 281-287.

Kranis, H.D., and Lekkas, E.L., 2000. The Pavliani fault zone: Evidence for westward propagation of the North Anatolian Fault Zone in Eastern Mainland Greece, Proc. IESCA 2000 , 2529.9.2000, (Abs.) 48p.

Kranis, H.D., Palyvos, N., Livaditis G., and Maroukian, H., 2001. The Hyambolis Zone: geomorphological and tectonic evidence of a transverse structure in Lokris (Central Greece), Bull. Geol. Soc. Greece, XXXIV/1, 251-257

Kranis, H.D., 1999. Neotectonic Activity of Fault Zones in central-eastern Mainland Greece (Lokris), Ph.D. Thesis. GAIA, 10, 2003, 234pp.

Kranis, H.D., 2002. Kinematics of active faults in Lokris, central Greece - block rotation within a crustal-scale shear zone? In J. Michalik, L. Simon and J. Vozar (eds), Proc. XVII Congress of the Carpatho-Balkan Geol Ass., Geologica Carpathica, 53, 157-159.

Leeder, M.R., and Jackson, J.A., 1993. The interaction between normal faulting and drainage in active extensional basins, with examples form the western United States and central Greece, Bas. Res., 5, 79-102.

Lemeille, F., 1977. Études néotectoniques en Grèce centrale nord-orientale (Eubée centrale, Attique, Béotie, Locride) et dans les Sporades du Nord, Thèse, Univ. Paris XI.

Makris, J., Papoulia, J., Papanikolaou, D., and Stavrakakis, G., 2001. Thinned continental crust below northern Evoikos Gulf,central Greece, detected from deep seismic soundings, Tectonophysics, 341, 225-236.

Mariolakos, I., Kranis, H,. Maroukian, H., and Fountoulis, I., 2001. Tectonically controlled drainage evolution in Lokris, Bull. Geol. Soc. Greece, XXXIV/1, 175-782

McClusky, S.C., Balassanian, S., Barka, A., Demir, C., Ergintav, S., Georgiev, I., Gurkan, O., Hamburger, M., Hurst, K., Kahle, H., Kastens, K., Kekelidze, G., King, R., Kotzev, V., Lenk, O., Mahmoud, S., Mishin, A., Nadariya, M., Ouzounis, A., Paradissis, D., Peter, Y., Prilepin, M., Reilinger, R., Sanli, I., Seeger, H., Tealeb, A., Toksoz, M.N., and Veis, G., 2000. Global positioning system constraints on plate kinematics and dynamics in the eastern Mediterranean and Caucasus, Journal of Geophysical Research, 105, 5695-5719.

Metaxas, A., 1987. Geological investigation of Agnandi sub-region, Lokris, Unpubl. IGME report, Athens. (in Greek) 
Metaxas, A., 1992. Geological research on the lignite occurrence in the southern field of Agnandi Tahtali sub-region (Phtiotis), Unpubl. IGME report, Athens. (in Greek)

Metaxas, A., 1994. Results of research for lignite in the area "Tahtali-Rengini-Ag. Haralambos - Mendenitsa" in 1993, Unpubl. IGME report, Athens, 24pp. (in Greek)

Palyvos, N., Badekas, I., and Kranis, H., 2006. Transverse fault zones of subtle geomorphic signature in northern Evia island (central Greece extensional province): An introduction to the Quaternary Nileas graben, Geomorphology, 76, 363-374.

Philip, H., 1974. Etude néotectonique des rivages égéens en Locride et Eubée nord-occidentale (Grèce), Thèse doc. sp., Acad. de Montpelier, 86 p.

Pope, R.J., 2000. The application of mineral magnetic and extractable iron $\left(\mathrm{Fe}_{\mathrm{d}}\right)$ analysis for differ entiating and relatively dating fan surfaces in central Greece, Geomorphology, 32, 57-67.

Roberts, S., and Jackson, J., 1991. Active normal faulting in central Greece: an overview, In A.M. Roberts, G. Yielding and B. Freeman (eds), The Geometry of Normal Faults, Geol. Soc. Sp. Pub., 56, 125-142.

Sengör, A.M., 1979. The North Anatolian Transform fault: its age, offset and tectonic significance, J. Geol. Soc. London, 136, 269-282.

Sorel, D., 2000. A Pleistocene and still-active detachment fault and the origin of the Corinth-Patras rift, Greece, Geology, 28, 83-86.

Symeonidis, N., 1974. Ein Bemerkenswerter Wirrbeltierfund aus dem Lignit von Atalanti (Phthiotis, Griechenland), Ann. Geol. Pays Hell., XXVI, 306-314.

Taymaz, T., Jackson, J., and McKenzie, D., 1991. Active tectonics of the north and central Aegean Sea, Geoph. J. Int., 106, 433-490.

Tzanis, A., Chailas, S., and Kranis, H., 2004. Aeromagnetic and topographic constraints on the active tectonics of central Greece, Proc. 10th GSG Conference, 15-17.4.2004, Thessaloniki, Ext. Abs., 627-628. 